\title{
Bronchoesophageal fistula: a rare complication of non-small cell carcinoma (NSCLC) invading the mediastinum
}

\author{
Samreen Khuwaja, Ahad Azeem, Steven Guttmann
}

Internal Medicine, Long Island Jewish at Forest Hills, Forest Hills, New York, USA

\section{Correspondence to} Dr Ahad Azeem aazeem@northwell.edu

Accepted 24 June 2019

\section{DESCRIPTION}

An 80-year-old woman presented with complaints of progressive difficulty swallowing associated with productive cough, brownish sputum and shortness of breath. She had known history of $7 \mathrm{~cm}$ lung mass diagnosed 6 months prior to admission as an incidental finding on routine chest X-ray followed by CT scan of chest (figure 1). Her bronchoscopy and biopsies were consistent with small cell carcinoma of lung and she underwent bronchoscopic fulguration few weeks later for reducing tumour burden.

At the time of admission, the patient was in mild respiratory distress. She had blood pressure of $140 / 90 \mathrm{~mm} \mathrm{Hg}$, heart rate 115 beats/min, respiratory rate 22 breaths/min with $92 \%$ room air saturation. Patient had an esophagogram (figure 2) to evaluate the cause of dysphagia during which patient immediately aspirated in her both right and left main stem bronchi indicating bronchoesophageal fistula
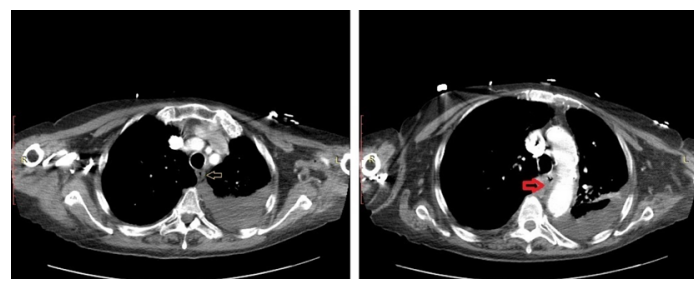

Figure 1 Chest CT scan demonstrating a large $6 \times 7 \mathrm{~cm}$ low-density left hilar cancer with mass effect on the posterior lateral oesophagus indicating bronchogenic carcinoma metastasising to the oesophagus.

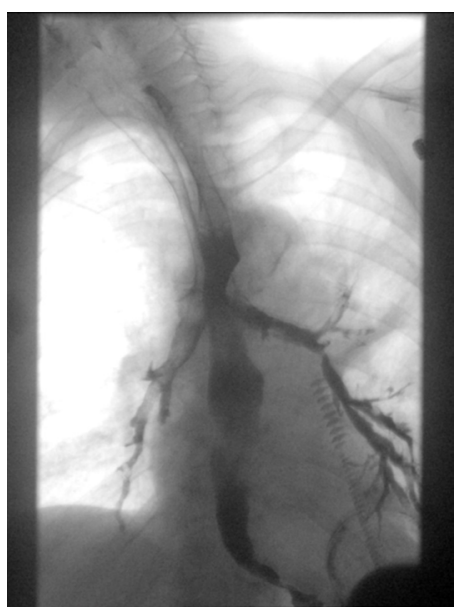

Figure 2 Barium esophagogram illustrating contrast aspiration in bilateral main stem bronchi.

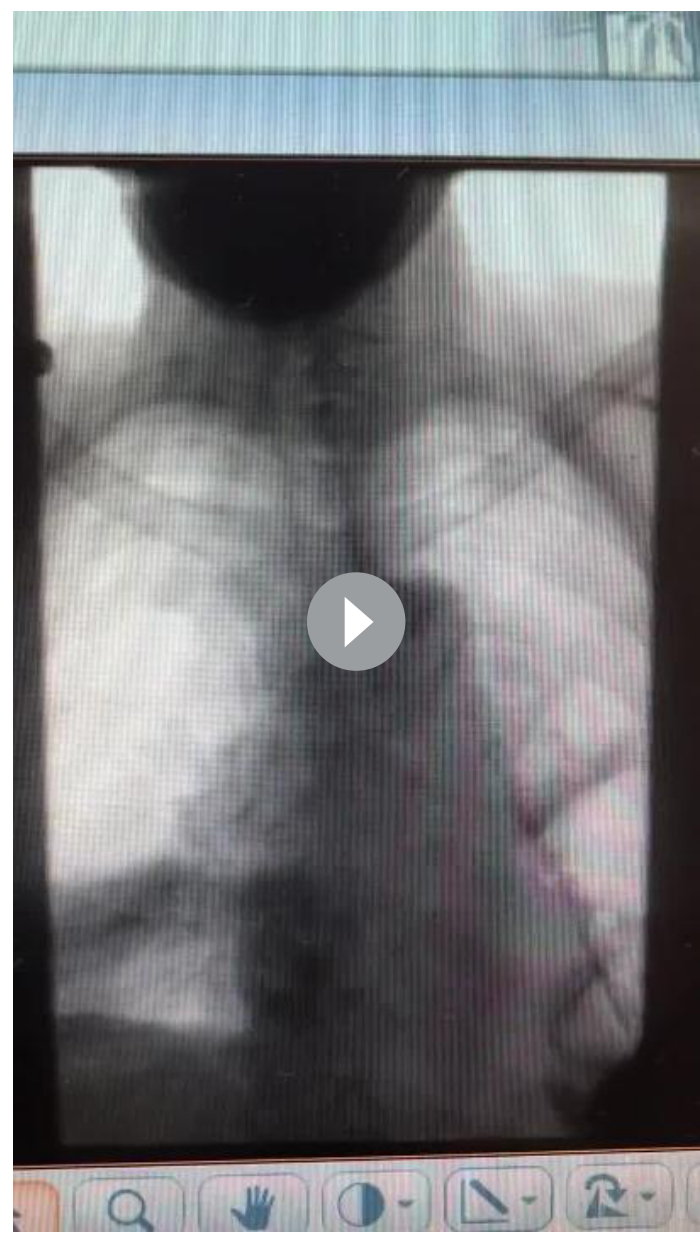

Video 1 Video file of the contrast esophagogram.

(BEF) formation (video 1). Her follow-up chest $\mathrm{X}$-ray showed aspirated contrast in bilateral lower lung fields with small pleural effusions. Despite the presence of symptoms, patient was a poor surgical candidate for repair of fistula or gastrostomy tube placement and was referred to palliative care.

In literature, reported incidence of BEF secondary to carcinoma of lung is $0.3 \%$ and only $<1 \%$ are caused by bronchogenic carcinoma of lung. ${ }^{12}$ Mortality risk increases significantly from the cancer in the setting of BEF formation due to aspiration pneumonia and overall deterioration in health. ${ }^{1}$ The aetiology of BEF is chronic inflammation, infections, iatrogenic or penetrating thoracic trauma and malignancies. For a physician, it can be a therapeutic challenge to diagnose due to its atypical presentation. Most common symptoms of BEF is cough after having oral fluid 
intake (Ono's sign), dysphagia, recurrent pulmonary infections, malnutrition and sepsis. ${ }^{34}$ Barium esophagogram is the most reliable exam for detection of BEF. ${ }^{4}$ Treatment includes thoracotomy, video-assisted thoracoscopic surgery, silicon prosthesis, sclerosing substance injection at fistula site via endoscopy, bare metal stent and self-expending metal stents. ${ }^{34}$

\section{Learning points}

- Common symptoms of bronchoesophageal fistula (BEF) are paroxysmal cough, coughing after oral fluid intake (Ono's sign), dysphagia, recurrent pulmonary infections, malnutrition and sepsis.

- Barium esophagogram is a most sensitive exam for detection of BEF.

- Clinical suspicion for BEF should be high in patients who presents with symptoms of dysphagia, recurrent pneumonia and sepsis in presence of known neoplastic conditions.
Contributors SK prepared the manuscript draft with the assistance of AA. AA reviewed and edited the manuscript. SG provided intellectual inputs and the images from the procedure performed.

Funding The authors have not declared a specific grant for this research from any funding agency in the public, commercial or not-for-profit sectors.

Competing interests None declared.

Patient consent for publication Next of kin consent obtained.

Provenance and peer review Not commissioned; externally peer reviewed.

\section{REFERENCES}

1. Abugroun $A$, Ahmed F, Singh $N$, et al. Late Onset Chemo/Radiation Induced Tracheoesophageal Fistula in Squamous Cell Cancer of the Lung. World I Oncol 2017;8:171-3.

2. Stavrou G, Rafailidis V, Kouskouras K, et al. Bronchoesophageal fistula due to metastatic mediastinal lymphadenitis. ANZ I Surg 2019;89:E170-E171.

3 Ginesu GC, Feo CF, Cossu ML, et al. Thoracoscopic treatment of a broncho-esophageal fistula: A case report. Int I Surg Case Rep 2016;28:74-7 http://www.ncbinlm.nih.gov/ pubmed/27689523.

4 Argüder E, Aykun G, Karalezli A, et al. Bronchoesophageal fistula. J Bronchology Interv Pulmonol 2012;19:47-9.

Copyright 2019 BMJ Publishing Group. All rights reserved. For permission to reuse any of this content visit https://www.bmj.com/company/products-services/rights-and-licensing/permissions/

BMJ Case Report Fellows may re-use this article for personal use and teaching without any further permission.

Become a Fellow of BMJ Case Reports today and you can:

- Submit as many cases as you like

- Enjoy fast sympathetic peer review and rapid publication of accepted articles

- Access all the published articles

Re-use any of the published material for personal use and teaching without further permission

\section{Customer Service}

If you have any further queries about your subscription, please contact our customer services team on +44 (0) 2071111105 or via email at support@bmj.com.

Visit casereports.bmj.com for more articles like this and to become a Fellow 